\title{
Isomorphic and decoupling processes: an empirical analysis of governance in Italian state museums ${ }^{1}$

\author{
Claudio Nigro - Enrica Iannuzzi - Miriam Petracca
}

\begin{abstract}
Purpose of the paper: This study, which adopts a situationist perspective, analyzes the governance dynamics of Italian museum organizations. It focuses on the role played by the actors involved in the governance practices of the national artisticcultural heritage, the institutional pressures brought to bear on the conduct of museum directors, and the initiation of isomorphic and decoupling processes by the actors.

Methodology: We conducted field research to verify the presence of isomorphic and decoupling processes in the strategic behavior of directors who are responsible for Italian state museums. To this end, we developed descriptive, cluster, and crosstabulation analyses.

Findings: The field research first detected a widespread emphasis on the protection of artistic-cultural heritage. Secondly, it revealed a tendency for museum directors to adopt isomorphic and decoupling strategies.

Research limits: Although the situationist perspective enabled a more realistic representation of the phenomenon, it did not provide a set of prescriptive, ready-to-use governance practices.

Practical implications: These new insights into the governance of museums from the situationist perspective should stimulate the sector's actors to review the use of predictive models and to acquire the skills needed to understand the competitive nature of institutional environments. The study should also show the way for further studies on the role of directors and a wider understanding of this topic.

Originality of the paper This study gives the reader the opportunity to recognize isomorphic and/or decoupling processes as the inevitable result of a fragmented regulatory framework.
\end{abstract}

Key words: governance; museums; situationist perspective; isomorphism; decoupling

\section{Introduction}

The governance of museum organizations in Italy is a topical issue, given the wealth of the nation's artistic-cultural heritage and, simultaneously, the limited resources available for its promotion. Although cultural objects are widespread throughout the country, the museum sector reflects the problems

The article is the result of the joint work of the authors. In the editing phase, Claudio Nigro oversaw paragraphs 1, 4.2, 4.2.1, 4.2.2 and 4.2.3, Enrica Iannuzzi focused mainly on sections 2 and 5, and Miriam Petracca oversaw paragraphs 3 , 4, 4.1 and 4.2.4. 
sinergie Vol. 34, N. 99, 2016

arising from a fragmented institutional framework, discontinuous public policies, a dearth of available funds, and the overlap of responsibilities among several bodies with different - and sometimes conflicting - visions of the future (Wizemann and Alberti, 2005).

In particular, the fragmentation of the institutional framework is reflected in the way actors behave as a result of a partial definition of their roles and responsibilities. Such situations involve an overlap between the central and peripheral organs engaged in museum governance, the difficulty of establishing a power hierarchy and a clear commitment among the actors, and a wide gulf between the concrete actions taken by a museum's director and the market's expectations. Specifically, a museum's director or executive seems to operate between instances of autonomy, ascribed in the institutional framework, and political pressure from other key institutional actors, who are both directly and indirectly involved in the museum's governance. In these circumstances, the director has to take a double risk. Unable to interpret and formulate an effective synthesis of the demands coming from the environment, and facing an increasing number of ways forward in conditions of great decisional uncertainty, the director is forced to adopt behaviors that conform to generally-accepted practices in the sector, even if these limit potential development.

The context and conditions described above are the subject of indepth analysis in the political and scientific domain. It is conceivable that the contributions made by researchers working on the governance of national cultural heritage may have helped public decision makers to promote a process of change that has, for a long time, empowered the entire regulatory structure. The process began with public decision makers combining the potential of the undisputed artistic and cultural heritage of the nation with an organizational structure equipped with managerial skills. Managerial skills should be designed to promote the managed assets, and to find the economic and financial resources necessary to maintain the/an organizational network among units within a particular area.

Consistent with this aim, scientific debate has turned its attention to the ability of cultural organizations to perform successfully (Golinelli, 2012; Montella, 2006, 2009, 2012), integrating the specific purpose of the sector, i.e. conservation of and access to culture, with purposes until now attributable to different economic sectors, namely, the economic, social, and environmental sustainability of the area (Tamma, 2010; Franch, 2010).

Following on from these preliminary considerations, the study initially describes the evolution of the institutional framework and identifies the institutional actors directly involved in the museum's governance, both central and peripheral. A brief review of the current literature on museum governance is also given.

The study then focuses on the dynamics of museum governance from a situationist perspective. This perspective allows the scholar to avoid studying the phenomenon in a deterministic logic or to avoid using an ex-ante explanation scheme. In the opinion of the writers, museum governance has to be read within an ex-post comprehension scheme. The power relations among the actors involved in the governance of these organizations and the influence of institutions on their activities led the 
research group to consider the phenomenon to be the result of the activation of two processes: action and institutionalization.

Using the situationist perspective, the study aims to identify: the role played by the actors involved in governance and management processes in state museum organizations, both directly and indirectly; and the power relations between these actors. Special attention is paid to the measures undertaken by central actors (state and regions) to direct the conduct of the actors of the strategic periphery (directors and executives).

In particular, the reconstruction of governance dynamics through the analysis of power relations among the actors allowed the research group to detect a tendency for museum organizations operating in the same organizational field to initiate isomorphic institutional processes. This development has interesting implications both from a scientific perspectivethe pursuit of better performance and the achievement of social legitimacyand from the regulatory aspect. The regulatory aspect is involved in integrating two important aspects related to museum management: 1) the constitutionally-guaranteed protection of artistic and cultural heritage; and 2) the promotion of this heritage, an idea that is linked to market competition.

If these considerations are true and the adoption of strategic modes of behavior is motivated, mostly or exclusively, by the achievement of social legitimacy, a director may then disregard market expectations in order to focus on issues related to the mere preservation of managed assets. He or she may then operate on ways to promote that heritage in a purely formal manner.

This process, commonly called decoupling, is understood as a disconnection between formally adopted actions that are intended as a response to institutional pressures to gain legitimacy, and their true scope (Orton and Weick, 1990; Oliver, 1991; Zucker, 2000; Kalev et al., 2006). In fact, decoupling creates a 'legitimacy façade', which is not aligned to the actual achievement of competitive standards, but is aimed at achieving what appear to be ostensible results.

In light of this scenario, the working group reflected on the existence of a trade-off between efficiency and legitimacy, as well as on the difficulties for directors to reconcile preservation and promotion objectives. Isomorphic and/or decoupling processes are therefore seen as the natural consequence of a cognitive and normative framework characterized by numerous points of weaknesses.

To this end, the conclusion presents the results of the field research, divided into two phases. The first phase isolates the elements that characterize museum governance and are useful in reconstructing the most frequently adopted governance model. The second phase, building on the results of previous research, focuses on isomorphism and decoupling processes.

\section{A brief reconstruction of the institutional framework: a focus on the actor involved in museum governance}

In order to better contextualize the phenomenon, this section presents a brief reconstruction of the evolution of the institutional framework for
Claudio Nigro Enrica Iannuzzi Miriam Petracca Isomorphic and

decoupling processes:

an empirical analysis of governance in Italian state museums 
sinergie

italian journal of Vol. 34, N. 99, 2016

museum governance. It should be noted that the regulation of museum governance has recently witnessed a profound change, with the Ministerial Decree of December 23 ${ }^{\text {rd }}$, 2014 (the Museums Decree), which defines the national museum system and determines its management methods.

Dario Franceschini, the current minister of the Ministry of Cultural Heritage and Tourism (Ministero dei Beni e delle Attività Culturali e del Turismo (MiBACT)) sees the decree as a tool to revolutionize the organization and functioning of Italian state museums. The decree will lead these organizations towards modernization, with modern organizations characterized by a high degree of managerialization and professionalization.

However, we can talk about relevant change only if we compare this with the guidelines that the government followed in their delineation of state museum governance.

Regulatory developments in the cultural heritage field have been considerably more active in recent years than in the past. A number of interventions have modified previous legislation dating back to the late 1930s. Even in the 1990s, cultural heritage still referred to objects of art. Since then, power, hitherto exclusively reserved for the state, has been allocated to regions and local authorities.

Figure 1 shows three separate guidelines that have characterized legislative intervention over this period. These three guidelines mark the transition from a vision of museum governance focused, in the first period, on the protection and preservation of cultural heritage, to a close interdependence between preservation and promotion in the second phase, and to the modernization of cultural heritage governance in the third phase.

Fig. 1: The managerialization process in the museum system

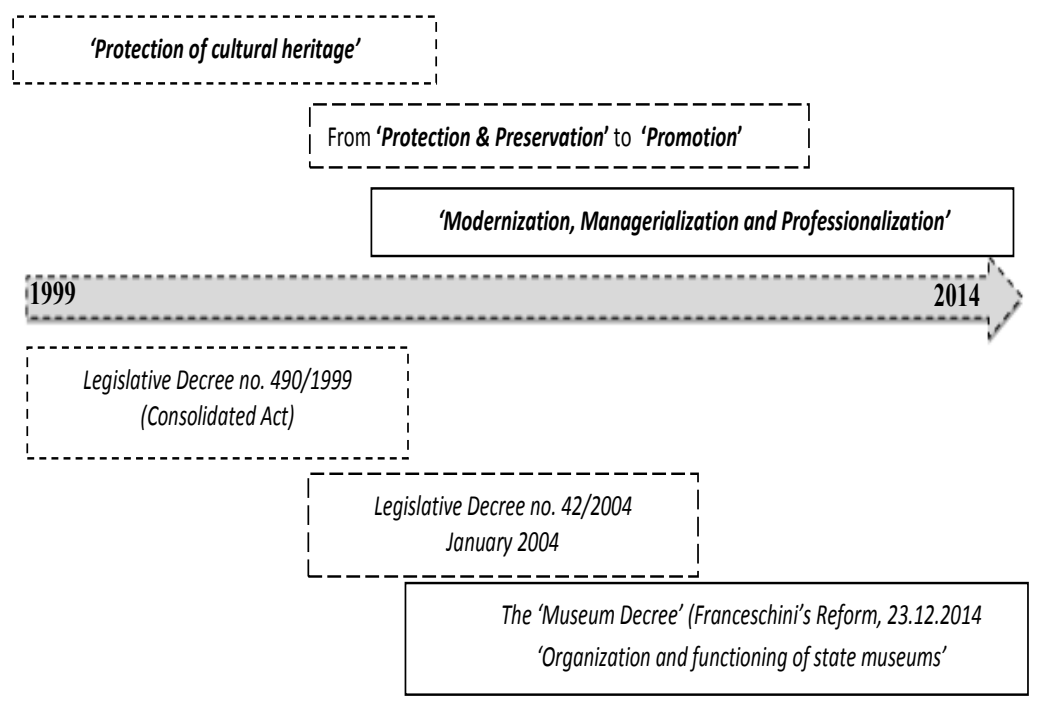

Source: personal elaboration 
The Museums Decree complements and amends the 1999 legislation (the Code of Cultural Heritage), which gave the cultural heritage system the overriding goal of ensuring its protection and conservation. At the same time, the idea of promotion, cited for the first time in Article 17, refers to "problems of special importance".

The emphasis did not change until 2004, with the Code of Cultural Heritage and Landscape 42, through which museum organizations received ad hoc regulation (Sandulli, 2012). In particular, this legislation enacts a transition from the concept of protecting and preserving artistic and cultural heritage to that of promotion. Nevertheless, museum governance continues to focus on the protection of cultural heritage, resulting in poor attention being paid to its promotion. This means that the action exerted by the central bodies leads to conflict with the strategic activities of museum directors.

However, the 2004 code did resolve many of the concerns regarding the meaning of cultural heritage despite the continuing presence of critical areas. The code's definition is based on the semantic distance of this concept from other concepts, such as the protection, management, and promotion of heritage. In addition, the new code overcame an elitist vision of the use of cultural heritage, consistent with the correct interpretation of the Italian Constitution (Art. 9 and 2) (Manfredi, 2011).

To sum up, a dynamic vision of the governance and management of cultural heritage emerged for the first time. This is oriented towards promotion (even if only in theory) in contrast to a static view centered on preservation. This change of vision produced a first useful impulse to define one of the director's tasks as being responsible for the promotion of culture and art, and the actions needed to achieve this. The promotion of artistic and cultural heritage requires important policies and actions that are in alignment with the guidelines provided by central and local governments (MiBACT, regions, provinces, and regional superintendents) (Scuillo, 2010).

This brief analysis facilitates a reconstruction of the aims behind museum governance but also brings out its complexity. It is clear that the particular role played by the actors responsible for museum governance (the directors and executives), includes protection and preservation activities as well as the promotion of national cultural heritage. The actors attempt to preserve their autonomy and, at the same time, respond to the pressure coming from political actors who have contributed to their appointment (a process which can turn into nepotism).

To date, museums lack effective autonomy and appropriate managerial qualifications and are subject to the decision-making power exercised by central bodies. The effort to cut through this complexity has led to a substantial change of direction in political debate. The new direction taken by the government to modernize the administration of cultural heritage is centered on the managerialization process described above. The Museums Decree, which represented the start of Italian political debate on museum governance, marks a transition from a system of governance and management that is dependent on experts, to a system entrusted to professionals. As a result, today's Italian museum system comprises 20 independent museums with a network of 17 regional centers responsible
Claudio Nigro

Enrica Iannuzzi

Miriam Petracca

Isomorphic and

decoupling processes:

an empirical analysis of governance in Italian state museums 
sinergie Vol. 34, N. 99, 2016

for promoting a continuing dialogue between the various museums and creating an integrated offer for the public. Aside from the organizational aspects, the principal change introduced by this decree is the appointment of museum directors who are chosen from among the top experts in the fields of governance and management. This is because museums, hitherto more limited in their potential, have been reevaluated not only as places of protection and promotion, but as places of culture that are connected with a specific locality.

We cannot comment on the potentiality of this new regulatory framework yet. We will have to wait to evaluate its effectiveness in terms of the professionalization and managerialization of skills and improved performance (Nigro et al., 2015a; Nigro et al., 2015b).

As noted, the new regulatory provisions look at general principles without resolving the overlap of jurisdiction between a number of institutional actors, all holding responsibility for the preservation and promotion of heritage.

The reconstruction of the regulatory framework turns on the axis of the protection and preservation/promotion of cultural heritage. However, to understand the logical and conceptual gap between these two issues, it is necessary to answer organizational concerns clearly defining the areas of responsibility of the institutional actors involved in the dynamics of museum governance. For this reason, the study looks briefly at legislative guidelines about the competence that is attributed to institutional actors (the state, regions, local authorities, and superintendents) in museum governance (Table 1).

Table 1 shows close interdependence and a clear overlapping of roles and responsibilities among actors involved at different levels of museum governance. In most cases, this produces a conflict of jurisdiction.

The potential risk resulting from this overlap became clear when a conflict between actors required the intervention of the Constitutional Court (in this case, decision no. 9 of 2004), which, unable to resolve the overlap between state and regional expertise, enforced the principle of loyal cooperation in order to shed light on the many gray areas of the regulatory framework. This principle, also known as the principle of state/ region subsidiarity, has determined the juxtaposition of interests between the involved public bodies. In other words, the principle that evokes local autonomy paradoxically creates the conditions for the peripheral actor to be aligned to the central role, thus ignoring the expectations of the area or region. In addition, the competence of museum directors was not referred to in the legislation outlined in Table 1 until the recent Museums Decree. This decree, simply resuming the Code of Ethics of the International Council of Museums (ICOM), failed to identify the specific knowledge or skill set that should characterize the role of the museum director. At this point, it should be pointed out that, in the opinion the researchers, legislation provides only a partial view of the dynamics behind the governance of museums, inspiring them to adhere to the principle of spreading culture, already constitutionally protected. Conversely, the dynamics that contribute to creating value should be redesigned with a focus on the market, placing strategic emphasis on the action undertaken 
by those actors who contribute to the definition of the rules thanks to a temporary negotiation of power.

Tab. 1: The actors included in the governance of Italian cultural heritage as per legislation
Claudio Nigro Enrica Iannuzzi Miriam Petracca Isomorphic and decoupling processes: an empirical analysis of governance in Italian state museums

\begin{tabular}{|c|c|}
\hline Actors & Areas of competence \\
\hline Central State & $\begin{array}{l}\text { Exclusive jurisdiction in matters of "protecting the landscape and } \\
\text { the historical and artistic heritage of the Nation" (art } 9 \text { of the Italian } \\
\text { Constitution; Constitutional Court judgment } \mathrm{n}^{\circ} 9 \text { of } 2004 \text {; art. 4, } \\
\text { paragraph } 1 \text { of Code of cultural heritage and landscape, Legislative } \\
\text { Decree. } 42 / 2004 \text { ); } \\
\text { Legislative power of the State, limited to providing the basic principles } \\
\text { with which regions are required to comply (art. } 117 \text { and } 118 \text { of the } \\
\text { ltalian Constitution) }\end{array}$ \\
\hline $\begin{array}{l}\text { Supreme Council of } \\
\text { Cultural Heritage } \\
\text { and Landscape }\end{array}$ & $\begin{array}{l}\text { Staff organ of the ltalian Ministry, having technical-scientific } \\
\text { meaning for culturaI heritage and landscape (art. } 13 \text { D.P.R. 233/2007, } \\
\text { "Regulation for the reorganization of the Ministry of Cultural Heritage } \\
\text { and Activities"). }\end{array}$ \\
\hline Regions & $\begin{array}{l}\text { Concurrent legislation (State-regions) on the "enhancement of } \\
\text { cultural and environmental promotion and organization of cultural } \\
\text { activities" (Art 117, paragraph } 3 \text { of the ltalian Constitution; Principle } \\
\text { of State-Regions subsidiarity); } \\
\text { Forms of agreement and coordination ('parallelism' principle) } \\
\text { between the State and regions regarding the protection/promotion of } \\
\text { cultural heritage (Art. 118, paragraph } 3 \text { of the ltalian Constitution; } \\
\text { Code of Cultural Heritage and Landscape, Legislative Decree 42/2004; } \\
\text { Constitutional Court judgment } n^{\circ} 9 \text { of 2004, referred to on several } \\
\text { occasions for the resolution of issues of overlapping jurisdiction } \\
\text { between the State and regions). }\end{array}$ \\
\hline $\begin{array}{l}\text { Peripheral } \\
\text { Administration } \\
\text { (Superintendence) }\end{array}$ & $\begin{array}{l}\text { Peripheral body of the Ministry of Cultural Heritage and Tourism, "it } \\
\text { carries out the institutional tasks of protection exercised according } \\
\text { to the Code of Cultural Heritage and Landscape, Legislative Decree } \\
\mathrm{n}^{\circ} 42 / 2004 \text {, within the area of its jurisdiction" (D.P.R. 233/ 2007, } \\
\text { "Regulation for the reorganization of the Ministry of Cultural Heritage } \\
\text { and Activities"). }\end{array}$ \\
\hline $\begin{array}{l}\text { Local bodies } \\
\text { (metropolitan } \\
\text { cities, provinces and } \\
\text { municipalities) }\end{array}$ & $\begin{array}{l}\text { Administrative functions and duties from the State to the regions } \\
\text { and locaI authorities (Legislative Decree } n^{\circ} 112 \text { of March 31st, 1998; } \\
\text { Consolidated Acts, Legislative Decree } 490 / 1999 \text { ); } \\
\text { Criterion for asset ownership for competent promotion (Code of } \\
\left.\text { Cultural Heritage and Landscape, Legislative Decree } n^{\circ} 42 / 2004\right) \text {; } \\
\text { Distribution of responsibilitiesbetween theState, regions, metropolitan } \\
\text { cities, provinces and municipalities "to support the conservation of } \\
\text { cultural heritage and its public use and promotion".(Art. 1, paragraph } \\
3 \text { of the Code of Cultural Heritage and Landscape, Legislative Decree } \\
\left.n^{\circ} 42 / 2004\right) \text {. }\end{array}$ \\
\hline
\end{tabular}

Source: Nigro et al. (2016)

The provisions of the legislation concerning promotion should be directed by market principles. However, to enter the market it is necessary for an organization to operate in an orderly manner. Museums have entered a competitive arena in which there is an evaluator-the consumer or userwho can freely choose whether or not to visit a museum. At the same time, the museum's director is given a concrete context for activity in which the legislation also provides for other actors who are to be involved in museum governance and capable of influencing the choices that the director wishes to make. 


\section{sinergie}

Vol. 34, N. 99, 2016

\section{Literature review}

As already mentioned in the introduction, scientific debate on this topic has been enriched with interesting contributions that have explored the traits that are characteristic of the governance and management of Italy's artistic and cultural heritage. In particular, recent years have seen the gradual emergence of a sharp focus on the managerialization process in cultural organizations. This is in line with new guidelines that reflect the current change of direction by public decision makers with regard to cultural governance. For this reason, the scientific debate can be interpreted in the light of an evolutionary process that has affected - and continues to influence - the institutional framework.

Current economic and managerial literature has repeatedly indicated that managerialization is the direction to take in order to overcome the difficulties that characterize the dynamics of managing Italy's cultural heritage (Wizemann and Alberti, 2005; Nigro et al., 2011). However, the managerialization process is not new in the public sector. With regard to the organization of state museums, it is considered as a way forward from a system that was traditionally centered on protection and conservation. At the same time, it creates opportunities to make the promotion of culture and the area or region to which it belongs concrete.

The areas of scientific debate that clearly reinterpret the political debate include the argument that traditional governance, suited to the protection and conservation of heritage, now faces a more innovative form of governance, which is more suitable for to the promotion of its heritage, and a close interdependence between culture and the area or region to which it belongs. Both arguments converge in the culture of managerialization, with its emphasis on the actor responsible for the organization and for the promotion of its professionalization (Rullani, 2004; Golinelli, 2008; Solima, 2010; Tamma, 2010; Franch, 2010; Montella 2006; 2009; 2012).

The introduction of the idea of culture promotion in the regulatory framework calls for the creation of culture management, a discipline that has still not been defined in terms of its positioning in the fields of management, administration, strategic planning, management control, organization, and marketing (Franch, 2010). It is, however, closely linked to the role of cultural professions in value creation (Dragoni, 2010; Golinelli, 2012; Montella, 2006; 2009; 2012; Manacorda and Montella, 2014) in terms of local sustainability and cultural heritage. The culture manager builds the "context of culture-user interaction", which effectively manages and controls the process of socialization (Tamma, 2010). The culture manager rediscovers - in art and culture - "local development factors in the same way as the availability of material factors or specific environmental resources" (Franch, 2010, p. 98); he or she enhances the cultural resources of a single museum, in line with the locality, making the cultural experience unique.

Nonetheless, in an effort to propose corrective action for these critical issues, the outcome of the scientific managerial debate consists of the transfer of interpretive schemes to the museum sector that is typical of traditional management. However, this produces a short-sighted and, at times, rhetorical vision, turning its attention mainly to strategies adopted 
by organizations devoted to the idea of promotion in order to analyze the actual ability to create value (Dragoni, 2010).

It should be emphasized that recent scientific debate has been enriched by business management studies that are focused on the organizational, economic and financial autonomy given to museum organizations by the current regulatory framework. This area of study has reconstructed the common features of museum organization and management, focusing on the efficient and effective use of scarce resources (Lord and Lord, 1997; Bagdadli, 2003; Bagdadli and Paolino, 2005), and connecting management success to improved economic performance.

\section{Methodology}

\subsection{The situationist perspective}

Situationist studies provide a theoretical reference for the reflections that this study proposes regarding the governance of museum organizations. This approach allows for the recovery of the centrality of the pro-tempore actor involved in governance dynamics. It focuses on the concrete context of human action in daily life and on the role of social actors who contribute to the definition of the observed reality (Garfinkel, 1967; Berger and Luckmann, 1969; Sparti, 2002).

At a theoretical level, this perspective can be understood through a synthesis of political and new institutionalism perspectives. The political perspective (Crozier and Friedberg, 1978; Pfeffer, 1981; Friedberg, 1994; Crespi, 1999) is centered on the social actors who adopt particular strategies to pursue their own interests. These actors enact mechanisms of cooperation, conflict, and negotiation and attempt to increase their influence and power. Although not intended, this creates, preserves and transforms governance assets. The new institutionalism perspective (Meyer and Rowan, 2000; Powell and DiMaggio, 2000; Zucker, 2000) investigates the impact of the institutional framework on the social actors' behavior. Institutions, as well as their material and symbolic conditionings, are the result of the work of the same actors who tend to crystallize rules and constraints in order to create a local order. Between action (the political perspective) and institutionalization (the new institutionalism perspective) emerges a vision of an actor who, in performing his deliberate acts, does not surrender his nature as a strategic subject, albeit bound by the institution (Mastroberardino, 2006; 2010).

The synthesis between action and institutionalization enabled studies to analyze the dynamics of museum governance through the actions taken by the actors who are directly involved. In fact, actors evoke spaces of autonomy-a maneuver margin-without being able to waive the requirement of liability imposed by the pro-tempore defined institutional framework. This is the case of museum directors who, in demonstrating their responsibility, choose to make their behavior conform to institutional pressures and rules, thereby initiating isomorphism processes because of their own interests, glimpsed opportunities and perceived threats (Oliver, 1991). In this way, responsibility, understood as the search for social legitimacy, is preferred to autonomy.
Claudio Nigro

Enrica Iannuzzi

Miriam Petracca Isomorphic and

decoupling processes:

an empirical analysis of governance in Italian state museums 
Sinergie Vol. 34, N. 99, 2016

It is interesting to note that, in many aspects, compliance with requests from central institutions may conflict with technical efficiency, even though it can be understood as responsible behavior that ensures the social legitimacy of the actor (Meyer and Rowan, 1977).

However, the answer to the demands of compliance may be only ceremonial, 'a form of confidence game' (Pfeffer, 1982), resulting in a decoupling dynamic, the gap between the formal actions that are carried out and their true extent (in terms of strategic effectiveness). In fact, decoupling represents a formal compliance that gives rise to window dressing. This ostensibly meets the regulators' obligations and increases the external perception of legitimacy, whereas managing the organization continues as before (Meyer and Rowan, 1977; Weaver et al., 1999).

The situationist perspective therefore enables the identification of the fact that museum governance, while crystallizing in a pro-tempore institutional asset, never gives rise to a conclusive and immutable frame (Barley and Tolbert, 1997; Mastroberardino, 2006, 2010; Mastroberardino and Nigro, 2009; Nigro and Trunfio, 2010). For this reason, museum governance should be studied in its dynamic form; the focus of the analysis becomes the institutional pressures and the power relations between the institutional players both directly and indirectly involved in the dynamics of museum governance. The network of relationships woven between institutional actors leads organizations to look alike because of the isomorphic conduct adopted by museum directors; the latter, in responding to pressure, allow their decision-making autonomy to be reduced mainly to acquire social legitimacy.

In line with this theoretical framework, the following sections present highlights from the field research conducted by the working group. The aim is to find isomorphism and decoupling phenomena that are used in state museum organizations in order to create apparent legitimacy.

\subsection{Field research}

The situationist perspective allows the research group to state that there is no universally valid governance model and that there are no effective and efficient management models for the state's artistic-cultural heritage. Therefore, the complexity of the corporate governance of Italian museums cannot be addressed and explained in a unified way. In other words, a universally applicable model of governance does not exist, and there are no predetermined actions that can ensure the effective and efficient management of all museums (Friedberg, 1994).

For the above reasons, the group conducted quali-quantitative field research with regards to the governance dynamics of local museums in an Italian context. The survey was divided into two phases.

\subsubsection{First phase of the field research}

The first phase was developed in the paper "An empirical analysis of governance dynamics in the Italian State Museums", which was presented at the International Conference in Heritage, Tourism and Hospitality 
(HTHIC, 2014). The paper reconstructs the traits that characterize governance dynamics in national museum organizations. In particular, the research group conducted this phase starting from the following assumptions: there is a gap between the contents of the Code of the cultural heritage and landscape and the organizational structure, internal processes, and activities of museum organizations; the key actors in governance processes adopt a strategic approach mainly directed towards the protection of artistic and cultural heritage; and initiatives aimed at marketing artistic and cultural heritage are limited.

The research group has conducted a preliminary Delphi analysis, interviewing three key players in the museum sector, who are experts in preservation, management, and marketing. From their answers emerge relevant elements that qualify museum governance as static or dynamic. These elements are classified on the basis of two main factors: the structure and services provided by the museums (65 items); and the opinions expressed by the respondents, in relation to some aspects of governance and management (18 items).

The research group set up an ad hoc questionnaire made available online to the directors responsible for Italian state museums (ISTAT 2012: 209 Italian state museums and galleries; respondents: 57 units). The survey enabled the research group to isolate the elements that characterize the governance of museum organizations and to give exploratory guidelines aimed at rebuilding the governance model adopted by most museum organizations.

In order to reduce the large number of elements to be analyzed and propose a dynamic reading of the investigated processes, the research group has carried out the following analyses: factor analysis, in which the items related to the structure and services provided by the museums are synthesized in a few factors; cluster analysis, in which museums are classified on the basis of opinions expressed by respondents; and discriminant analysis, which allows for an understanding of the weight of each factor, based on value judgments expressed by respondents.

\subsubsection{Results of the first phase of field research}

The results from the first phase of the field analysis are used as input for the formulation of the hypotheses of the second phase. The results suggest that a complex phenomenon such as museum governance cannot be explained on the basis of ex-ante, deterministic or causal approaches. Rather, these results confirm the importance of interest-driven actors, who interact within a pro-tempore building institutional framework.

This preliminary research allows a broader reconstruction of the investigated phenomenon, taking into account both the directors' efforts to bring forth their strategies according to the principle of autonomy, and the inevitable structural constraints on their action deriving from the roles they play. The directors' actions seem to move between the pressure coming from the institutional environment that can influence their actions and directors' efforts to exert governance and management autonomy, which is explicitly foreseen by the provisions of the law.
Claudio Nigro

Miriam Petracca Isomorphic and decoupling processes: an empirical analysis of governance in Italian state museums 
sinergie Vol. 34, N. 99, 2016

These considerations identify that individual actors, in order to build and consolidate their legitimacy and preserve their reputation in the socio-cultural and political environment, are inclined to adapt the organizational structure and operations to the values and rules governing those environments regardless of the actual effectiveness of this strategy in pursuing organizational objectives. In doing so, actors attempt to "replace diversity and heterogeneity with institutionalization and isomorphism" (Martinez, 2011, p. 18). The results of cluster analysis confirm this consideration: they show the recurring actions taken by the interviewed actors, to the point that isomorphic strategies can be considered persistent in museum governance, generally leading to a conservative managerial approach. As detailed in the above-mentioned article, the survey confirms that the directors of small museums typically pursue conservative policies, following a static governance approach that is focused on the protection and preservation of artistic-cultural heritage. Another group, focused on marketing artistic-cultural heritage, does exist, but it represents a minority.

\subsubsection{Second phase of the field research}

The results of the first phase of the field research, which identified the centrality of the actor in the institutional environment as well as his or her willingness to implement isomorphic behavior, provided the input for the second phase of the field research. This phase, conducted under the sponsorship of MiBACT, is aimed at identifying isomorphic and decoupling processes in Italian museum organizations. It must be noted that the work is still ongoing and that the working group defers the presentation of the results of the entire research till later studies. For this reason, here we only present the results for the following research hypotheses:

Hp1: The museums' directors initiate isomorphic processes, making their strategic behavior conform to predefined schemes and institutionalized rules;

Hp2: The actions taken by the directors and executives of museum organizations conform to decoupling processes.

To this end, the research group has revisited the survey instrument to make it more consistent with the hypotheses to be validated. This revision concerns upgrading the activities that characterize government and management orientation (static or dynamic) and the inclusion of statements, in the opinion section, that can detect the presence or absence of potential gaps between what respondents say and what they do. These possible differences are valid elements signaling potential isomorphism and/or decoupling processes. The items relating to structure and services offered by museums was decreased from 65 to 59 items; the opinions relating to aspects of governance and management were increased from 18 to 20 items.

The questionnaire was made available online to the entire population of directors in charge of public museum organizations. To increase the respondent sample, the research team also phoned directors who had not responded. There were 72 responses (34.45\% of the population). However, it should be noted that many directors are in charge of more than one 
museum organization; despite this, the research team decided to consider their answers valid for only one particular museum.

In order to analyze the presence of isomorphic and decoupling processes, the research group has developed the following types of analysis: descriptive analysis, cluster analysis, and cross-tabulation.

\subsubsection{Results of the second phase of the field research}

Descriptive analysis

Descriptive analysis was conducted on the items that were most suitable for the research hypotheses. Before presenting the results, we present the institutional positions held by the respondents (Table 2).

Tab. 2: Position of respondent

\begin{tabular}{|l|c|c|c|}
\hline & Frequency & Percentage & Cumulative percentage \\
\hline Director & 47 & 65.3 & 65.3 \\
\hline Superintendent & 25 & 34.7 & 100.0 \\
\hline
\end{tabular}

Source: personal elaboration

The analysis shows that $65 \%$ hold the position of director, whereas $25 \%$ of respondents hold the role of superintendent in addition to their role as director of a museum organization.

To analyze the presence of isomorphism and decoupling processes, the research group selected and analyzed agreement/disagreement with three items: 1) the museum director has the autonomy to define strategic choices for the marketing and development of the structure he or she manages (Table 3 ); 2) routine schemes are carried out in the museum even if they tend to achieve results that do not allow for the full promotion of cultural heritage (Table 4); and 3) the legal liability of the museum director and the absence of any assurance from the ministry acts as a disincentive to engage in activities aimed at marketing and risk taking (Table 5).

Tab. 3: Item 1: Director's autonomy in making strategic choices

\begin{tabular}{|l|c|c|c|}
\hline & Frequency & Percentage & Cumulative percentage \\
\hline Strongly disagree & 10 & 13.9 & 13.9 \\
\hline Disagree & 36 & 50.0 & 63.9 \\
\hline Agree & 24 & 33.3 & 97.2 \\
\hline Strongly agree & 2 & 2.8 & 100.0 \\
\hline
\end{tabular}

Source: personal elaboration Claudio Nigro
Enrica Iannuzzi Miriam Petracca Isomorphic and

decoupling processes:

an empirical analysis of governance in Italian state museums 


\section{sinergie} Vol. 34, N. 99, 2016
Tab. 4: Item 2: Museum follows routine schemes even if they do not allow for marketing or promotion

\begin{tabular}{|l|c|c|c|}
\hline & Frequency & Percentage & Cumulative percentage \\
\hline Strongly disagree & 10 & 13.9 & 13.9 \\
\hline Disagree & 13 & 18.1 & 31.9 \\
\hline Agree & 40 & 55.6 & 87.5 \\
\hline Strongly agree & 9 & 12.5 & 100.0 \\
\hline
\end{tabular}

Source: personal elaboration

Tab. 5: Item 3: Legal liability of directors as a disincentive for promotional activities

\begin{tabular}{|l|c|c|c|}
\hline & Frequency & Percentage & Cumulative percentage \\
\hline Strongly disagree & 10 & 13.9 & 13.9 \\
\hline Disagree & 15 & 20.8 & 34.7 \\
\hline Agree & 38 & 52.8 & 87.7 \\
\hline Strongly agree & 9 & 12.5 & 100.0 \\
\hline
\end{tabular}

Source: personal elaboration

The results show that $64 \%$ of respondents expressed a negative opinion on the first item, arguing that they did not have sufficient autonomy to make strategic choices. There was a majority of positive opinions on the other two items, with regard to the adoption of routine schemes $(68 \%)$, and the fact that a director's legal liabilities did not facilitate promotional activities (65\%).

\section{Cluster analysis}

The clustering method used is K-Means with moving averages. This procedure allowed the research group to identify two relatively homogeneous clusters according to the selected variables, synthesizing different strategic approaches and the bias for and against museum promotion.

We grouped the activities that could represent an orientation towards promotion as follows: promotion of structure ( 3 items); and promotion of knowledge through research (item 3).

Accordingly, the items chosen for activities promoting the structure include the purchase of new items for exhibitions, local restructuring and outfitting renovations.

The research group selected these elements because, in its opinion, they represent the basic activities that museum organizations should develop on a daily basis to ensure better use of artistic-cultural heritage. The cluster analysis identified two clusters with respect to these three items (Tables 6 and 7), one oriented to preservation and the other to promotion. 
Tab. 6: Final cluster center: structure promotion

\begin{tabular}{|l|c|c|}
\hline \multicolumn{3}{|c|}{ Cluster } \\
\hline & 1- Preservation orientation & 2- Promotion orientation \\
\hline Purchase of new goods & No & Yes \\
\hline Local restructuring & No & Yes \\
\hline Outfitting renovation & No & Yes \\
\hline
\end{tabular}

Source: personal elaboration

Tab. 7: Number of cases in each cluster: structure promotion

\begin{tabular}{|l|l|l|}
\hline \multirow{2}{*}{ Cluster } & Preservation orientation & 27 \\
\cline { 2 - 3 } & Promotion orientation & 45 \\
\hline
\end{tabular}

Source: personal elaboration

The first cluster includes 27 museums (37\%) whose respondents declared that they do not carry out important activities for the promotion of the structure, whereas the second cluster brings together the 45 museums (63\%) oriented towards promotion.

The research group looked, in a similar way, at the items that promoted research: scientific catalogues, research projects and publications.

These items were selected due to the belief that they are activities that encourage better dissemination of knowledge regarding the Italian artistic and cultural heritage. For this second analysis, the algorithm processed two clusters (Tables 8 and 9).

Tab. 8: Final cluster center: research promotion

\begin{tabular}{|l|c|c|}
\hline \multicolumn{3}{|c|}{ Cluster } \\
\hline & 1- Preservation orientation & 2- Promotion orientation \\
\hline Scientific catalogues & No & Yes \\
\hline Research projects & No & Yes \\
\hline Publications & No & Yes \\
\hline
\end{tabular}

Source: personal elaboration

Tab. 9: Number of cases in each cluster: research promotion

\begin{tabular}{|l|l|l|}
\hline \multirow{2}{*}{ Cluster } & Preservation orientation & 22 \\
\cline { 2 - 3 } & Promotion orientation & 50 \\
\hline
\end{tabular}

Source: personal elaboration

The first cluster includes 22 museum organizations (31\%) in which there is no scientific promotion; the second cluster includes the remaining 50 museums $(69 \%)$ that are more oriented towards research promotion. It should be noted that the scientific catalogues item is not a deciding factor because, in general, the majority of the surveyed museums do not produce them, even when they participate in scientific projects with universities and research centers. 


\section{sinergie} Vol. 34, N. 99, 2016

\section{Cross-tabulation}

The cross-tabulation analysis detailed below (Tables 11-15) shows the relationship between promotion activities (structure and research) and the opinions of respondents on the director's autonomy in making strategic choices, the adoption of routines schemes, and the director's legal liabilities. To make the results clearer, the research group divided the opinions into two main classes: unfavorable opinions ("Strongly disagree" and "Disagree") and favorable opinions ("Agree" and "Strongly agree").

The following table shows the relationship between the promotion of the structure (Table 10) and research (Table 11) and opinions expressed on the director's autonomy in making strategic choices.

Tab. 10: Cross-tabulation structure promotion/director's autonomy

\begin{tabular}{|l|l|c|c|c|}
\hline \multirow{4}{*}{ Structure promotion } & \multicolumn{4}{|c|}{ Director's autonomy in strategie choices } \\
\cline { 2 - 5 } & & Unfavorable opinion & Favorable opinion & Total \\
\cline { 2 - 5 } & Yes & 17 & 10 & 27 \\
\cline { 2 - 5 } & No & 29 & 16 & 45 \\
\cline { 2 - 5 } & Total & 46 & 26 & 72 \\
\hline
\end{tabular}

Source: personal elaboration

Tab. 11: Cross-tabulation research promotion/director's autonomy

\begin{tabular}{|l|l|c|c|c|}
\hline \multirow{4}{*}{ Research promotion } & \multicolumn{4}{|c|}{ In museums routine schemes are carried out even if they do not } \\
facilitate promotion
\end{tabular}

Source: personal elaboration

The analysis shows that $64 \%$ of respondents expressed a negative opinion, namely, that directors do not have the autonomy to define strategic choices for the promotion and development of the museum organization. Nevertheless, $37 \%$ do develop activities aimed at promoting the structure and $30 \%$ claim to undertake research promotion. At the same time, $22 \%$ and $26 \%$ of the sample, respectively, although claiming that the director has adequate management autonomy, do not actually initiate promotion, structure, and research activities.

The relationship between routine schemes, and structure and research promotion are presented in Tables 12 and 13. 
Tab. 12: Cross-tabulation structure promotion/routine schemes

\begin{tabular}{|c|c|c|c|c|}
\hline \multirow{5}{*}{ Structure promotion } & \multicolumn{4}{|c|}{$\begin{array}{l}\text { In museums routine schemes are carried out even if they do not } \\
\text { facilitate promotion }\end{array}$} \\
\hline & & Unfavorable opinion & Favorable opinion & Total \\
\hline & Yes & 8 & 19 & 27 \\
\hline & No & 15 & 30 & 45 \\
\hline & Total & 23 & 49 & 72 \\
\hline
\end{tabular}

Source: personal elaboration

Tab. 13: Cross-tabulation research promotion/routine patterns

\begin{tabular}{|l|l|c|c|c|}
\hline \multirow{4}{*}{ Research promotion } & \multicolumn{4}{|c|}{ The director's legal liability disincentives promotion } \\
\cline { 2 - 5 } & & Unfavorable opinion & Favorable opinion & Total \\
\cline { 2 - 5 } & Yes & 5 & 17 & 22 \\
\cline { 2 - 5 } & No & 18 & 32 & 50 \\
\cline { 2 - 5 } & Total & 23 & 49 & 72 \\
\hline
\end{tabular}

Source: personal elaboration

From this analysis, it emerges that $68 \%$ of respondents state that routine schemes are followed even though they tend to achieve results that do not allow the full promotion of Italy's artistic-cultural heritage. However, 39\% of respondents who state that routine schemes are followed also declare that they develop structure promotion activities. In addition, 35\% state that they initiate activities aimed at promoting knowledge through research.

Finally, the following tables represent the relationship between the legal liabilities of museum directors, structure (Table 14) and research (Table 15) promotion.

Tab. 14: Cross-tabulation structure promotion/legal liability

\begin{tabular}{|l|l|c|c|c|}
\hline \multirow{4}{*}{ Structure promotion } & \multicolumn{4}{|c|}{ The director's legal liability disincentives promotion } \\
\cline { 2 - 5 } & & Unfavorable opinion & Favorable opinion & Total \\
\cline { 2 - 5 } & Yes & 6 & 21 & 27 \\
\cline { 2 - 5 } & No & 19 & 26 & 45 \\
\cline { 2 - 5 } & Total & 25 & 47 & 72 \\
\hline
\end{tabular}

Source: personal elaboration

Tab. 15 Cross-tabulation research promotion/legal liability

\begin{tabular}{|l|l|c|c|c|}
\hline \multirow{4}{*}{ Research promotion } & \multicolumn{4}{|c|}{ The director's legal liability disincentives promotion } \\
\cline { 2 - 5 } & & Unfavorable opinion & Favorable opinion & Total \\
\cline { 2 - 5 } & Yes & 7 & 15 & 22 \\
\cline { 2 - 5 } & No & 18 & 32 & 50 \\
\cline { 2 - 5 } & Total & 25 & 47 & 72 \\
\hline
\end{tabular}

Source: personal elaboration 
Sinergie Vol. 34, N. 99, 2016

In the sample, $65 \%$ give a favorable opinion on the possibility that the legal liability of a museum's director can actually discourage promotion and risk taking. Despite that, $45 \%$ of the sample claim to have initiated activities aimed at promoting the structure and $32 \%$ say that they are carrying out research promotion.

\section{Discussion and conclusion}

In the opinion of the writers, reflections on museum governance in this study reinforce the consistency of the adopted approach. In fact, the situationist perspective allows the reconstruction of the phenomenon under investigation. This enables the analysis of governance dynamics through the observation of the effects that are produced. It should be noted that the crystallization of museum governance posited by the Museums Decree may, over time, confirm or contradict the reflections so far proposed once the new organizational structure is established. This is because the current regulatory framework, which is the result of the emergence of new political-institutional coalitions, partially redesigns areas of strategic action within which new museum directors and executives can move.

The analysis has revealed that there is a gap between the expressed opinions (as a direct result of the way that the current regulatory framework is perceived) and the actual activities that are developed in museums. As a result, decision makers seem to opt for solutions that adapt their internal processes to more stringent rules. And, as mentioned during this discussion, a greater weight has to be found with regard to the conservation of the public good represented by the heritage that is preserved in the museum. The initiation - by directors and executives - of behavior that indicates the existence of isomorphic and decoupling processes serves to mitigate risk. In particular, cluster analysis shows that the larger group would be more oriented towards promotion, even if a more conservative approach was preferred. Therefore, the analysis of the opinions expressed by the respondents suggests that de facto the development of promotion activities is not expedient. Logically, if the interviewee declares that: a) the decisionmaking autonomy of directors has the character of mere formality; b) it is more appropriate to follow schemes and routines that have already been established and implemented elsewhere; and c) the legal liability of the director can be a disincentive to risk taking but that, nevertheless, all promotional activities are sponsored, only one of the following hypotheses can be true. Either they are stating opinions they do not believe in or they are attempting to transmit an image of the museum that is not real. However, the research group believes that, because of the senior (and therefore sensitive) position of the respondents, the reported percentages concerning agreement/disagreement with the expressed opinions may have been underestimated (in favor of a positive representation of the status quo). This did not happen, however. The option to declare the hypothesis of the presence of isomorphic behaviors (i.e. behavior that tends to adjust internal processes to the regulatory framework) valid derives directly from $68 \%$ of the (in our opinion, underestimated) respondents, who say that the 
behavior adopted by the museum director ensures that his or her strategic actions conform to established practices in the institutional environment. $60 \%$ of those who have found the adoption of routine schemes a limit to the promotion and marketing of artistic-cultural heritage and who then said that they did not carry out any promotion activity, either in terms of structure or research, support the validity of hypothesis $\mathrm{Hp} 1$.

Decoupling processes represent the other side of the same coin. These processes identify a gap between what the respondents declare (opinions) and what they do (structure and research promotion activities). To confirm this, we found that more than $30 \%$ of respondents declaring that directors do not have the decision-making autonomy to define their strategic options nevertheless say that they develop activities aimed at promoting structure and research. In addition, more than $30 \%$ of respondents declaring that routine schemes are followed in museum organizations also claim to develop activities to promote structure and research. Finally, approximately $40 \%$ of respondents who expressed a favorable opinion on the limitations arising from legal liability for the actions taken by directors then claimed to have developed activities aimed at structure and research promotion. The hypothesis of the presence of decoupling is the only way to resolve this paradoxical situation. Logic would dictate that adaptation to routine and established practices should be a direct result of an imitation of best practices, which would therefore be able to generate value. However, reality portrays a museum system that is unable to express its full potential in economic terms. As a result, respondents attempt to show a version of the museum system that is different from the real one, creating a sort of window dressing in which the museum organization only formally adapts to the expectations of the organizational field.

From a methodological point of view, it should be noted that the questionnaire was mainly completed online. It therefore lacks interaction between interviewer and interviewee. This lack of direct contact does not allow us to frame the phenomenon in its full complexity. In addition, the sample size is limited. Although there was a response rate of approximately $34 \%$ of the surveyed population (72 reporting units out of the 209 units that were contacted), the specific identity of the museum sector, as well as the strong heterogeneity of museum organizations, suggests that the analysis should be extended in order to resolve critical issues.

\section{References}

BAGDADLI S. (2003), "Museum and theatre networks in Italy: determinants and typology", International Journal of Art Management, vol. 6, n. 1, pp. 19-29.

BAGDADLI S., PAOLINO C. (2005), The Institutional Change of Italian Public Museums Between Legitimacy and Efficiency: Do Museum Directors Have a Role?, neumann.hec.ca

BARLEY A., TOLBERT P.S. (1997), "Institutionalization and structuration: studying the links between action and institution", Organization Studies, vol. 18, n. 1, pp. 93-117. 
sinergie Vol. 34, N. 99, 2016

BERGER P.L., LUCKMANN T. (1969), La realtà come costruzione sociale, Il Mulino, Bologna.

CRESPI F. (1999), Teoria dell'agire sociale, Il Mulino, Bologna.

CROZIER M., FRIEDBERG E. (1978), Attore sociale e sistema. Sociologia dellazione organizzata, Etas Libri, Milano.

DRAGONI P. (2010), Processo al museo. Sessantanni di dibattito sulla valorizzazione museale in Italia, Edifir, Firenze.

FRANCH M. (2010), "Le frontiere manageriali per la valorizzazione della cultura e dell'arte", Sinergie, n. 82, pp. 95-107.

FRIEDBERG E. (1994), Il potere e la regola. Dinamiche dellazione organizzata, Etas Libri, Milano.

GARFINKEL H. (1967), Studies in Ethnometodology, Blackwell, Oxford.

GOLINELLI C.M. (2008), La valorizzazione del patrimonio culturale: verso la definizione di un modello di governance, Giuffrè, Milano.

GOLINELLI G.M. (2012), Patrimonio culturale e creazione di valore. Verso nuovi percorsi, Cedam, Padova.

KALEV A., DOBBIN F., KELLY E. (2006), "Best practices or best guesses? Assessing the efficacy of corporate affirmative action and diversity policies", American sociological review, vol. 71, n. 4, pp. 589-617.

LORD B., DEXTER LORD G. (1997), The Manual of Museum Management, The Stationary Office, London.

MANACORDA D., MONTELLA S. (2014), "Per una riforma radicale del sistema di tutela e valorizzazione", in Volpe G. (eds.), Patrimoni culturali e paesaggi di Piglia e d'Italia tra conservazione e autonomia. Atti delle Giornate di Studio, EdiPuglia, Bari.

MANFREDI G. (2011), "La valorizzazione dei beni culturali come compito costituzionalmente necessario", Il Capitale culturale. Studies on the Value of Cultural Heritage, vol. 3, pp. 25-31.

MARTINEZ M. (2011), Cambiamento e tradizioni di ricerca negli studi organizzativi: tra conservazione e distruzione, allomorfismo e isomorfismo, Working paper series, 3, CESIT, Napoli, p.18.

MASTROBERARDINO P. (2010), "La governance del sistema impresa tra istituzionalizzazione e azione del soggetto imprenditoriale”, Sinergie, n. 81, pp. 135-170.

MASTROBERARDINO P. (ed.) (2006), Lobbying. Agire tra vincoli, ESI, Napoli.

MASTROBERARDINO P., NIGRO C. (eds.) (2009), Le dinamiche di governance d'impresa. Cenni sullapproccio etnometodologico, ESI, Napoli.

MEYER J.W., ROWAN B. (1977), "Institutionalized Organization: Formal Structures as Myth and Cerimony", American Journal of Sociology, vol. 83, n. 2, pp. 41-62.

MEYER J.W., ROWAN B. (2000), "Le organizzazioni istituzionalizzate. La struttura formale come mito e cerimonia”, in Powell W.W., Dimaggio P.L. (eds), Il neoistituzionalismo nell'analisi organizzativa, Ed. Comunità, Torino.

MONTELLA M. (2006), "Approccio manageriale ai musei italiani", in Fiocca R., Battaglia L. (eds.), Il museo tra cultura e management, McGraw-Hill, Milano, pp. 51-70.

MONTELLA M. (2009), Valore e valorizzazione del patrimonio culturale storico, Mondadori, Milano. 
MONTELLA M. (2012), "Valore culturale”, in Golinelli G.M., Patrimonio culturale e creazione di valore. Verso nuovi percorsi, Cedam, Padova.

NIGRO C., IANNUZZI E., CAROLILLO G. (2011), “Comunicazione e strutturazione di un quadro istituzionale. Riflessioni sulla recente crisi del sistema finanziario", Sinergie, n. 89, pp. 109-130.

NIGRO C., TRUNFIO M. (2010), “Confini, coalizioni e governance nei contesti territoriali. Verso la realizzazione dei sistemi turistici locali”, Sinergie Rapporti di Ricerca, n. 31, pp. 47-89.

NIGRO C., IANNUZZI E., LAMBRESA M. (2014), "An empirical analysis of governance dynamics in the Italian State Museums", Proceedings of Heritage, Tourism and Hospitality: International Conference HTHIC 2014, pp. 322-337.

NIGRO C., IANNUZZI E., PETRACCA M. (2016, in pubblication),”'The Governance Dynamics in Italian State Museums", in Alvarez M.D., Ytiksel A., Go F.M. (a cura di) Heritage Tourism Destinations: Preservation, Communication and Development, CABI, Wallingford, UK.

NIGRO C., IANNUZZI E., PETRACCA M. (2015a), "How Universities institutionalize 'good' managerial practices? Some evidence from the Italian cultural sector", Proceedings of Toulon-Verona Conference "Excellence in Services” 2014, pp. 373-386.

NIGRO C., IANNUZZI E., PETRACCA M. (2015b), 'Cultural management' between isomorphism and decoupling”, Proceedings of $10^{\circ}$ International Forum on Knowledge Asset Dynamics (IFKAD) 2014 in Culture, Innovation and Entrepreneurship: connecting the knowledge dots, pp. 1837-1848.

OLIVER C. (1991), "Strategic responses to institutional processes", Academy of Management Review, vol. 16, n. 1, pp. 145-179.

ORTON J.D., WEICK, K.E.(1990), "Loosely Coupled Systems: A Reconceptualization”, Academy of Management Review, vol. 15, n. 2, pp. 203-223.

PFEFFER J. (1981), Power in organizations, Ballinger Publishing Company, Cambridge, MA.

POWELL W.W., DIMAGGIO P.L. (2000), Il neoistituzionalismo nell'analisi organizzativa, Ed. Comunità, Torino.

RULLANI E. (2004), Economia della conoscenza. Creatività e valore nel capitalismo delle reti, Carocci Editore, Roma.

SANDULLI M.A. (2012), Codice dei beni culturali e del paesaggio, Giuffrè, Milano.

SCIULLO G. (2010), "Il ruolo della produzione legislativa per la valorizzazione”, Il Capitale Culturale. Studies on the Value of Cultural Heritage, vol. 1, n. 1, pp. 119-122.

SOLIMA L. (2010), "Social Network: verso un nuovo paradigma per la valorizzazione della domanda culturale", Sinergie, n. 82, pp. 47-74.

SPARTI D. (2002), Epistemologia delle scienze sociali, Il Mulino, Bologna.

TAMMA M. (2010), "Prodotti culturali e territori: l'immateriale che "vive" nella materialità", Sinergie, n. 82, pp. 27-46.

WEAVER G.R., TREVINO L.K., COCHRAN P.L. (1999), "Integrated and decoupled corporate social performance: Management commitments, external pressures, and corporate ethics", Academy of Management Journal, vol. 42, n. 5, pp. 539-552.

WIZEMANN A., ALBERTI F. G. (2005), "L'assetto organizzativo della fondazione per la gestione dei beni e delle attività culturali", Liuc Papers Serie Management ed economia della cultura, vol. 1, n. 175, pp. 1-32. .
Claudio Nigro

Enrica Iannuzzi

Miriam Petracca Isomorphic and

decoupling processes:

an empirical analysis of governance in Italian state museums

(1) 
sinergie

italian journal of management Vol. 34, N. 99, 2016
ZUCKER L.G. (2000), "Il ruolo dell'istituzionalizzazione ai fini della persistenza culturale", in Powell W.W., DiMaggio P.J. (eds.), Il neoistituzionalismo nell'analisi organizzativa, Edizioni Comunità, Torino.

\section{Academic or professional position and contacts}

\section{Claudio Nigro}

Full Professor of Management

University of Foggia - Italy

e-mail: claudio.nigro@unifg.it

\section{Enrica Iannuzzi}

Researcher of Management

University of Foggia - Italy

e-mail: enrica.iannuzzi@unifg.it

\section{Miriam Petracca}

Researcher of Management

Giustino Fortunato University - Italy

e-mail:m.petracca@unifortunato.eu

sinergie italian journal of management

ISSN 0393-5108 DOI $10.7433 / \mathrm{s} 99.2016 .13$ pp. $241-262$

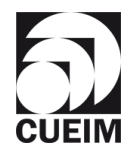

